\title{
SELECTED DATA DESCRIBING STREAM SUBBASINS \\ IN THE REDWOOD RIVER BASIN, SOUTHWESTERN MINNESOTA
}

By D. L. Lorenz and G. A. Payne

\begin{abstract}
This report presents selected data describing the characteristics of streams upstream from selected points on streams in the Redwood River basin. The points on the streams include outlets of subbasins of about five square miles, sewage treatment plant outlets, and U.S. Geological Survey gaging stations in the basin.
\end{abstract}

\section{INTRODUCTION}

The Redwood River drains an area of 705 square miles located in southwestern Minnesota and drains areas of Lincoln, Lyon, Murray, Pipestone, Redwood, and Yellow Medicine Counties.

This report is the first of several planned gazeteers providing basin characteristics of streams in Minnesota. It provides selected data for selected points on streams in the Redwood River Basin. The selected points include outlets of subbasins of about five square miles, outlets from sewage treatment plants, and U.S. Geological Survey gaging stations on the streams.

\section{Methods}

U.S. Geological Survey 7-1/2 minute-series topographic maps were used as base maps to obtain the data recorded in this report. The drainage area boundaries and stream channels were recorded using a geographic information system (GIS). The data was stored in an Albers EqualArea projection. Database functions and other capabilities of the GIS were used to aggregate the data, determine drainage area of the subbasins, and determine stream channel lengths. Elevation data for the streams were recorded at the point where topographic contour lines intersected the stream traces. Points on the stream channel 10 percent and 85 percent of the stream channel length from the basin outlet to the drainage divide were located by the GIS and the elevations of these points were interpolated from the data recorded in the GIS. Stream slope was calculated from these data. Lake area and storage area data were calculated using the analytic capabilities of the GIS.

\section{Acknowledgements}

The Minnesota State Planning Information Center provided invaluable assistance with much of the digitizing and programing needed to produce this report. The Center's help is gratefully acknowledged.

\section{SIGNIFICANCE OF DRAINAGE AREA BOUNDARIES}

The subbasins reported here were delineated on the basis of topographic features and human activities recorded on the topograhic maps. Data from field inspection and recent drainage ditch maps were transferred to the topographic maps. 
Drainage basins do not have fixed boundaries. Human activities along basin divides and within the basin, such as the installation of storm sewers, the drainage of wetlands, and the diversion of streams may alter the stream's drainage area.

\section{EXPLANATION OF BASIN CHARACTERISTICS}

Table 1 is a list of selected basin characteristics for each of the subbasins in the Redwood River basin. The rank of the stream is shown by indentation and indicates the drainage pattern of the stream. The first-ranked river is the Redwood River. Tributary streams are indented two spaces per rank.

The data for drainage area, main-channel length, and main-channel slope are reported using three significant figures or rounded to the nearest hundredth of a unit. The data for lake area and storage area are reported using two significant figures or to the nearest tenth of a percent.

\section{GLOSSARY OF TERMS}

Downstream Order Number. - Distinctive numbers assigned to each gaging station to provide geographical location and identification. The numbers are assigned based on the downstream order for each minor basin. The first digit designates the major river basin. The last six digits designate the downstream order of the location.

Drainage area.--That area measured on a horizontal plane, enclosed by a topographic divide, within which direct surface runoff from precipitation normally flows by gravity into a stream above a specified point. This may include closed basins and other areas which do not contribute directly to surface runoff.

Lake Area.--The percentage of the drainage area covered by open water.

Length.--The total length of the main channel from the basin outlet to the drainage divide. The main channel is that stream which drains the greatest area of all streams in the basin.

Map Number.-This is an arbitrary number used to identify the subbasin. The number is based on the Minnesota Common Stream Number System. The last four digits of the seven-digit number is used. The first three digits are $\mathbf{2 7 0}$ for all basins and were omitted to clarify the map.

Outlet Location--Quarter-quarter section, quarter section, section, township, and range are given to locate the outlet of the basin.

Slope.-The average slope of the watercourse between points 10 and 85 percent of the distance along the main channel from the basin outlet to the drainage divide.

Storage Area.--The percentage of the drainage area covered by lakes, ponds, and marshes as shown on topographic maps.

Stream Name.--The name of the stream shown on the map. U.S. Geological Survey gaging stations are given the name of the stream on which they are located. Sewage treatment plants are identified as STP outlets. 


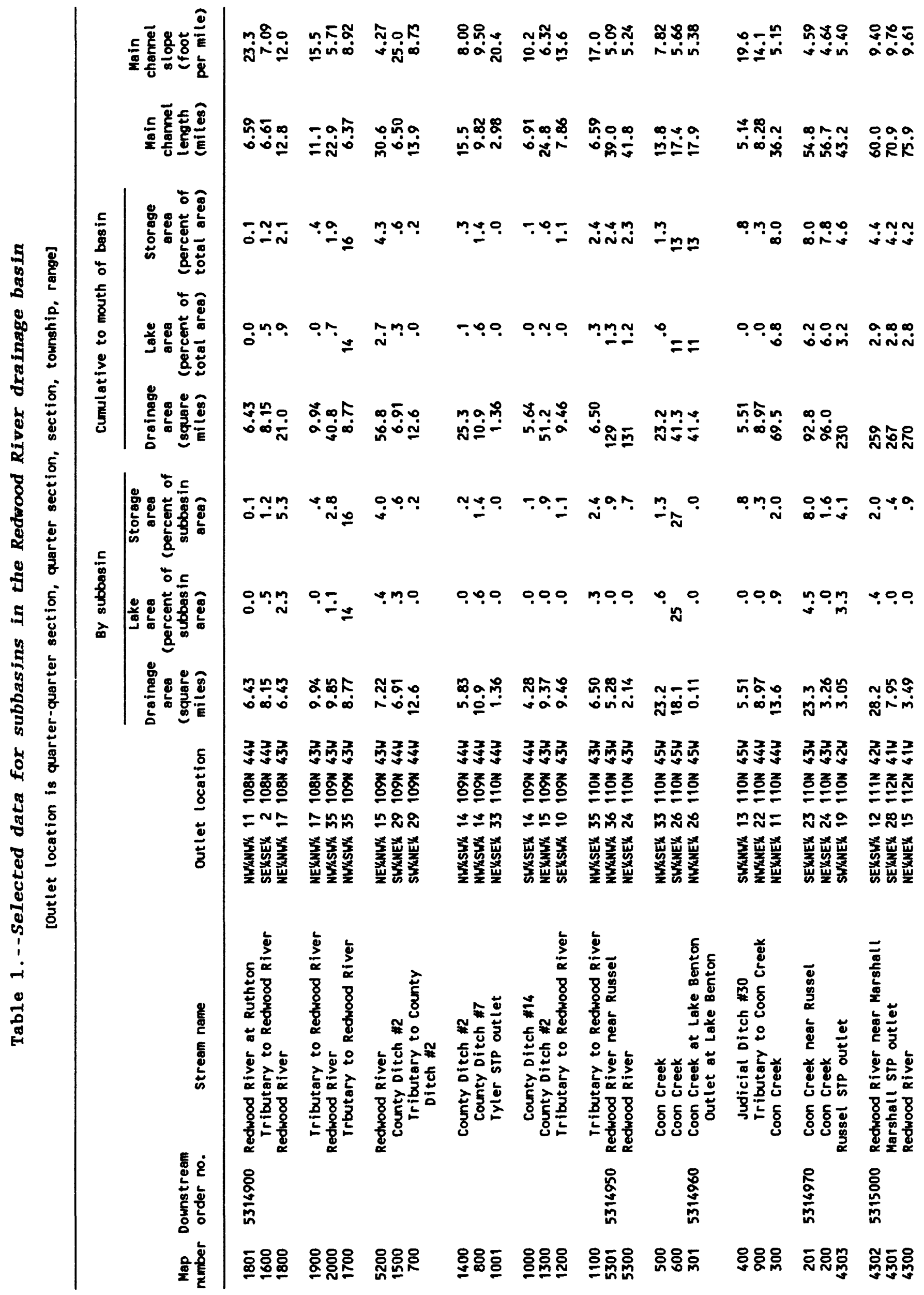




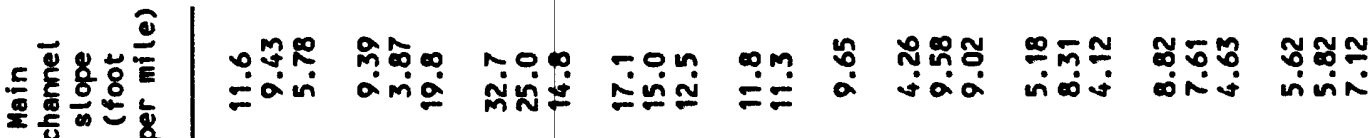

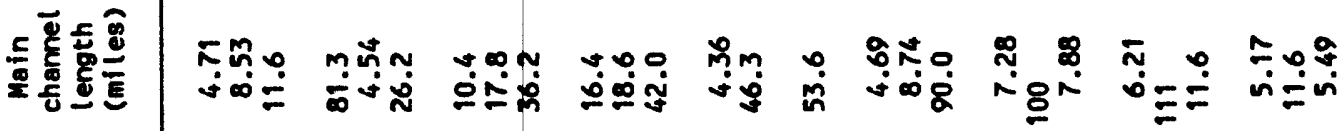

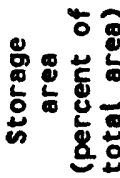

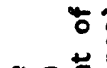

형웡

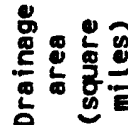

ペ=

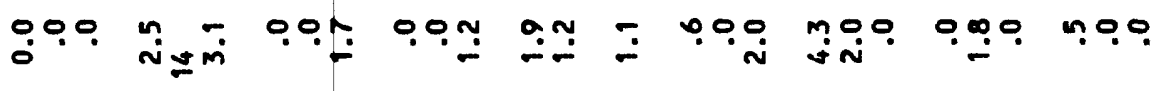

एँ

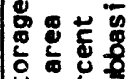

(6) .

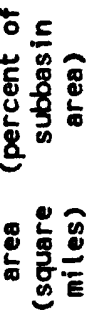

우. ".

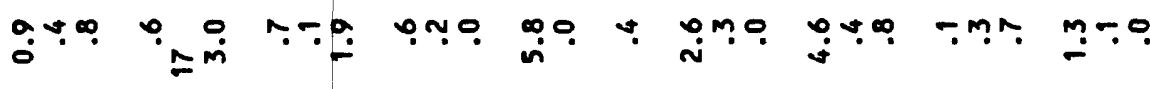

นำน nंजक

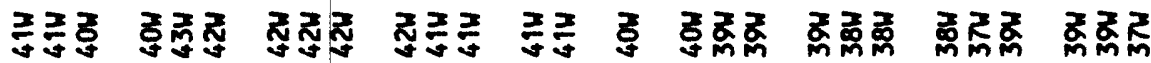

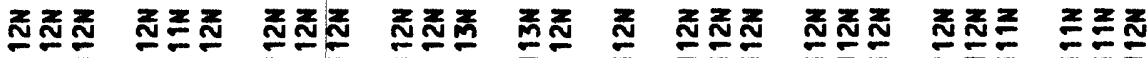

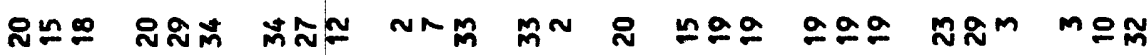

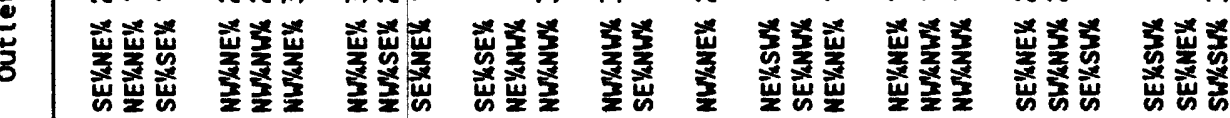

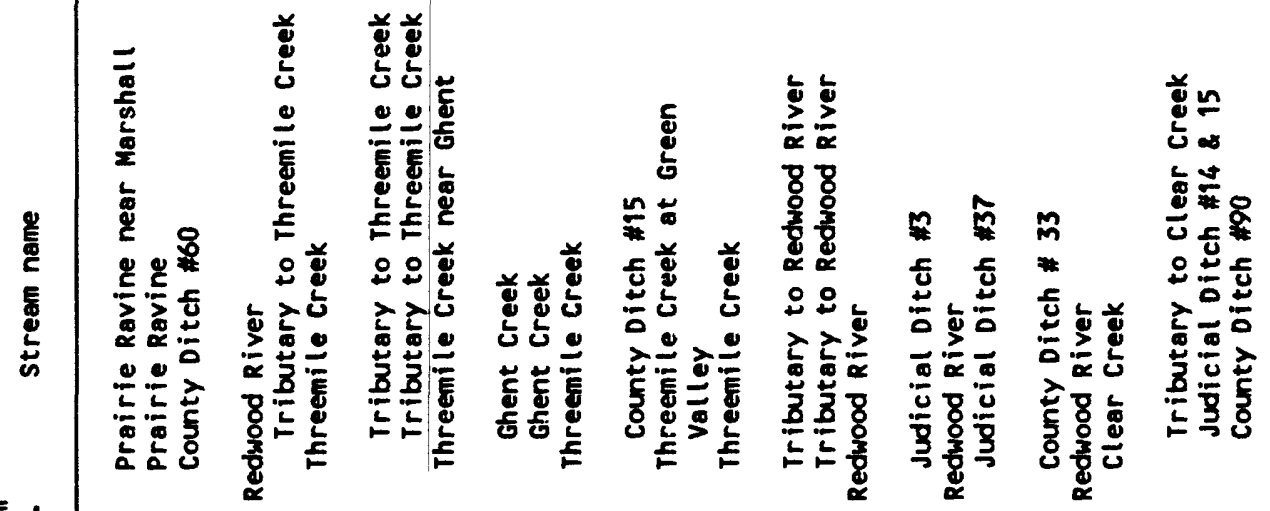

통요 ํㅛำ

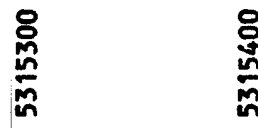

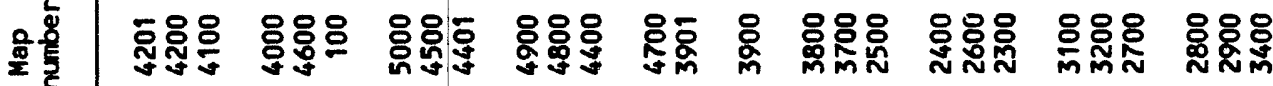




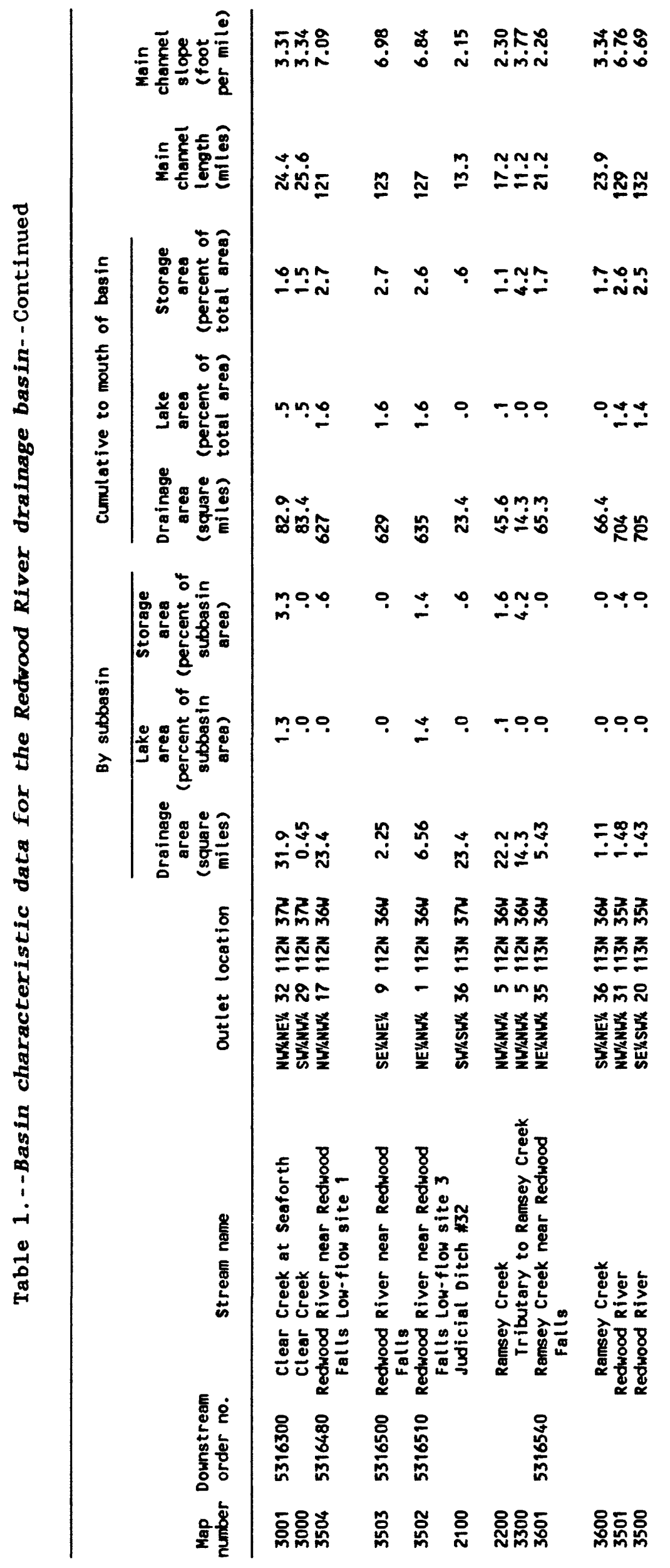

